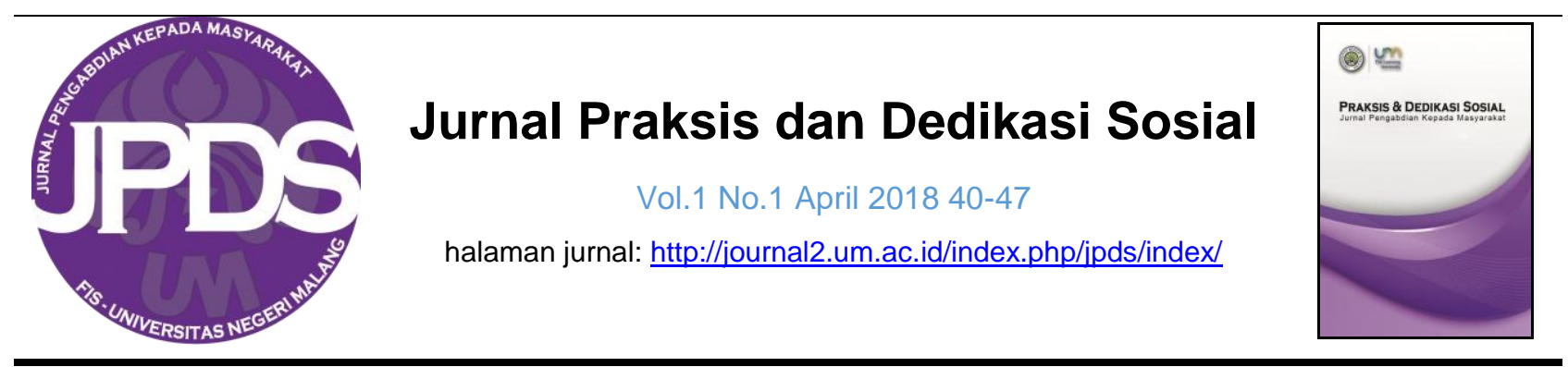

\title{
PELATIHAN DAN PENDAMPINGAN PENULISAN ARTIKEL JURNAL BAGI GURU-GURU IPS KABUPATEN MALANG
}

\author{
Neni Wahyuningtyas ${ }^{1}$, Nurul Ratnawati ${ }^{2}$ \\ 1,2 Prodi Pendidikan IPS, Fakultas IImu Sosial, Universitas Negeri Malang. \\ Diterima 15 Maret 2018, dipublikasikan 30 April 2018.
}

\begin{abstract}
Abstrak
Sebagai guru profesional tentunya harus memiliki berbagai kemampuan, salah satunya adalah kemampuan menulis karya ilmiah. Dengan menulis karya ilmiah selain guru dapat naik pangkat, jabatan dan golongan sehingga mengalami peningkatan karier, guru juga mendapatkan penghargaan dan pengakuan. Namun sayangnya kenyataan di lapangan menunjukkan bahwa banyak guru-guru yang belum menulis karya ilmiah yang dipublikasikan dalam jurnal maupun menjadi pemakalah pendamping di acara seminar nasional atau regional. Metode pelaksanaan kegiatan pengabdian ini adalah in-service training program yaitu pelatihan dan pendampingan kepada guru-guru IPS MTs Kabupaten Malang. Adapun langkah-langkah kegiatan yang ditempuh adalah koordinasi, penyemaian informasi, pendampingan, dan evaluasi. Hasil pengabdian menunjukkan jika sebagian besar guru-guru IPS Kabupaten Malang belum paham dan menguasai teknik penulisan karya ilmiah yang sesuai dengan aturan penulisan karya ilmiah. Selain itu peserta juga menjelaskan jika kesulitan mendasar yang banyak dialami dalam menyusun artikel yaitu merasa sulit ketika mengawali membuat penelitian, karena pada dasarnya penelitian ini akan dijadikan bahan dalan menyusun artikel. Kesulitan ini berawal dari tidak adanya ide yang akan dituangkan dalam penelitian. Ide tidak muncul karena budaya membaca dan menulis belum menjadi kebiasaan.
\end{abstract}

\section{Kata Kunci}

Artikel, Jurnal, Guru IPS

(C) 2018 Penulis

\section{PENDAHULUAN}

Undang-undang Nomor 20 Tahun 2003

Tentang Sistem Pendidikan Nasional, Undang-undang Nomor14 Tahun 2005 Tentang Guru dan Dosen, Peraturan Pemerintah Nomor 19 Tahun 2005 Tentang Standar Nasional Pendidikan dan Peraturan Pemerintah Nomor 74 tahun 2008 Tentang Guru mengamanatkan bahwa guru wajib memiliki kualifikasi akademik, kompetensi, dan sertifikasi pendidik yang sesuai dengan bidang tugasnya. Selain itu, guru juga dituntut untuk mengembangkan keprofesionalannya secara berkelanjutan dengan belajar sepanjang hayat. Sehubungan dengan hal tersebut pemerintah juga menguatkan dengan diterbitkannya Peraturan Menteri Negara Pendayagunaan Aparatur Negara dan Reformasi Birokrasi Nomor PER/16/M.PAN- 
RB/11/2009 tentang Jabatan Fungsional Guru dan Angka Kreditnya. Dalam Permen PAN tersebut, jabatan guru tidak lagi terdiri dari Guru Pratama hingga Guru Utama tetapi hanya terdiri dari 4 jenjang jabatan yakni: Guru Pertama (III/a dan III/b), Guru Muda (III/c dan III/d), Guru Madya (IV/a, IV/b, dan IV/c), Guru Utama (Pembina Utama Madya, golongan IV/d dan Pembina Utama, golongan IV/e). Hal tersebut tentunya memberikan dampak serta konsekuensi yang luar biasa bagi guru untuk mengembangkan kemampuan dan kompetensinya.

Sebagai guru profesional tentunya harus memiliki berbagai kemampuan, salah satu kemampuan yang harus dimiliki guru adalah kemampuan menulis karya ilmiah. Dengan menulis karya ilmiah selain guru dapat naik pangkat, jabatan dan golongan sehingga mengalami peningkatan karier, guru juga mendapatkan penghargaan dan pengakuan. Berarti menjadi begitu penting sekali memiliki kemampuan menulis karya ilmiah tersebut. Tetapi kenyataan di lapangan sebagian guru kemampuan menulis karya ilmiahnya masih rendah. Hal ini dibuktikan dengan pendapat Tatang (2006) saat ini sekitar 410.000 guru yang berpangkat IV/a masih mengalami kesulitan untuk kenaikan pangkat berikutnya karena adanya persyaratan menulis karya ilmiah.

Karya ilmiah tersebut merupakan persyaratan sertifikasi guru untuk proses kenaikan pangkat. Selain itu dengan dikeluarnya berbagai peraturan serta perundangan tersebut di atas, ternyata sebagian besar guru menanggapi dingin, rasa pesimistis tercetus pada para guru dengan ucapan "ahhhh, paling-paling kita jadi golongan III b abadi. Dengan kata lain guru merasa tidak sanggup untuk memenuhi segala persyaratan untuk kenaikan jabatan dan golongan tersebut.

Berdasarkan data Badan Kepegawaian Negara (BKN) tahun 2005 dalam Hadriyanto (2013) jumlah guru 1,4 juta, sebagian guruguru tersebut berada pada golongan III/a-III/d yang jumlahnya mencapai 996.926 guru dari sebanyak 336.601 golongan IV. Dari keseluruhan jumlah guru yang bergolongan IV terdapat $334.184(99,28 \%)$ yang golongan IV/a dan hanya 2,318 (0,69\%) golongan IV/b selebihnya golongan IV/c sebanyak $84(0,06$ $\%)$ guru dan golongan IV/d ada 15 (0,01\%). Artinya "ada tembok tebal tinggi yang sulit ditembus sebagian besar guru untuk naik pangkat dari golongan IV/a ke IV/b". Tembok ini semakin tebal dan tinggi dengan diberlakukannya Permen PAN-RB nomor 16 tahun 2009.

Menurut Hadriyanto (2013) menulis karya ilmiah adalah merupakan keharusan sebagai persyaratan akademis dan administrasi kepegawaian berkaitan dengan kenaikan pangkat dan jabatan. Begitu pentingnya Undang-undang No.14 Tahun 2005 Tentang Guru dan Dosen menyebutkan bahwa guru professional dibuktikan kemampuannya dalam menulis karya ilmiah yang menjadi syarat kenaikan pangkat dan jabatan. Begitu pula Peraturan Menteri (Permen) Pemberdayaan Aparatur Negara (PAN) dan Reformasi Birokrasi (RB) Nomor.16 Tahun 2009, tanggal 10 November 2009 tentang Jabatan 
Fungsional Guru dan Angka Kredit, dalam Pasal 16 Ayat (2) dinyatakan bahwa "Untuk kenaikan jabatan/pangkat setingkat lebih tinggi dari guru pertama, pangkat penata muda, golongan ruang IIla sampai dengan guru utama, pangkat pembina utama, golongan ruang IVe wajib melakukan kegiatan pengembangan keprofesian berkelanjutan yang meliputi sub unsur pengembangan diri, publikasi ilmiah, dan/atau karya inovatif. Sementara Pasal 17 menjelaskan bahwa kenaikan pangkat guru mulai dari golongan ruang III b ke atas dipersyaratkan mengajukan karya tulis ilmiah. Peraturan ini mulai berlaku tahun 2011 dan berlaku secara efektif mulai tanggal 1 Januari 2013, maka sejak tanggal tersebut

bahwa

kenaikan pangkat guru mulai dari golongan ruang III b ke atas dipersyaratkan mengajukan karya tulis ilmiah sudah berlaku. Ini menyisyaratkan kepada kita bahwa guru-guru harus melakukan pengembangan diri jika mengusulkan kenaikan jabatan/pangkat. Salah satu pengembangan diri yang dapat dilakukan oleh guru-guru adalah dengan membuat karya ilmiah yang dipublikasikan dalam jurnal ilmiah.

Namun sayangnya kenyataan di lapangan menunjukkan bahwa banyak guru-guru yang belum menulis karya ilmiah yang dipublikasikan dalam jurnal maupun menjadi pemakalah pendamping di acara seminar nasional atau regional. Selain itu diketahui jika sebagian besar guru-guru IPS Kabupaten Malang belum menguasai penulisan karya ilmiah yang sesuai dengan aturan penulisan karya ilmiah. Sehingga tidak mengherankan jika guru-guru tersebut mengalami kesulitan ketika kenaikan pangkat karena terbentur di faktor penulisan karya ilmiah.

Berdasarkan masalah di atas peneliti merasa tertarik untuk memberikan pelatihan dan pendampingan bagi guru-guru MGMP IPS SMP Kabupaten Malang untuk meningkatkan kemampuan menulis karya ilmiah guna pengembangan profesi kedepannya. Setelah kegiatan pelatihan penulisan karya ilmiah ini, peserta diharapkan mampu menulis karya ilmiah sehingga peserta mampu menulis artikel ilmiah yang kemudian dipublikasikan dalam jurnal. Untuk membantu guru-guru IPS dalam mempublikasikan hasil-hasil penelitian atau gagasan pemikiran kritisnya, Prodi S1 Pendidikan IPS memiliki suatu wadah komunikasi ilmiah yang berupa jurnal ilmiah yang bernama Jurnal Teori dan Praksis Pembelajaran IPS (JTP2IPS). Jurnal ini tidak hanya menampung hasil-hasil penelitian dari guru-guru IPS, tetapi juga untuk mempublikasikan karya dari seluruh peneliti, praktisi, pemerhati pendidikan, dan pengembang kurikulum, khususnya dalam bidang teori (Ilmu Sosial) dan pembelajaran IPS. Melalui media komunikasi berupa JTP2IPS ini, para peneliti dan praktisi dapat menyebarluaskan hasil-hasil penelitian dan gagasannya kepada masyarakat ilmiah sehingga masyarakat ilmiah dapat mengimplementasikan hasil-hasil penelitian atau gagasan kritis tersebut untuk meningkatkan kualitas pendidikan. Selain oleh guru-guru IPS, hasil-hasil penelitian yang dipublikasikan dalam JTP2IPS ini juga dapat 
Pelatihan dan Pendampingan Penulisan Artikel Jurnal Bagi Guru-Guru IPS...

dimanfaatkan oleh semua pemangku kepentingan, termasuk dinas pendidikan dan perguruan tinggi dalam rangka meningkatkan kualitas pendidikan.

Kenyataannya, jumlah artikel yang diharapkan dari guru-guru IPS sangat kurang. Untuk dapat memenuhi kebutuhan artikel yang berasal dari luar, pihak pengelola perlu melakukan sosialisasi JTP2IPS kepada

\section{Koordinasi}

Penulis berkoordinasi dengan guru-guru IPS Kabupaten Malang berkaitan dengan kegiatan pelatihan, terutama mengenai tempat dan jadwal pelaksanaan, serta perlengkapan dan bahan yang harus dipersiapkan peserta sebelum mengikuti kegiatan pelatihan seperti (laptop dan artikel yang minimal $50 \%$ jadi).

\begin{tabular}{|c|c|c|c|}
\hline $\begin{array}{l}\text { KOORDINASI } \\
\text { (Penentuan } \\
\text { tempat dan } \\
\text { jadwal } \\
\text { pelaksanaan) }\end{array}$ & $\begin{array}{l}\text { PENYEMAIAN } \\
\text { INFORMASI } \\
\text { (Hakikat karya } \\
\text { ilmiah dan artikel } \\
\text { jurnal) }\end{array}$ & $\begin{array}{c}\text { PENDAMPINGAN } \\
\text { (Praktik } \\
\text { penyusunan artikel } \\
\text { ilmiah) }\end{array}$ & $\begin{array}{l}\text { EVALUASI } \\
\text { (Mengukur } \\
\text { keberhasilan } \\
\text { program) }\end{array}$ \\
\hline
\end{tabular}

Gambar 1. Metode Pelaksanaan Kegiatan

penulis luar. Penulis luar yang paling layak disasar adalah guru-guru IPS. Seperti yang telah dijelaskan pada paragraf sebelumnya bahwa, secara umum kemampuan guru-guru IPS menulis artikel ilmiah masih sangat rendah. Oleh sebab itu, pelaksanaan kegiatan pengabdian ini bertujuan untuk: 1) meningkatkan pemahaman guru-guru IPS tentang penulisan artikel ilmiah; 2) melatih guru-guru IPS menulis artikel ilmiah; dan 3) menghasilkan artikel ilmiah yang akan dipublikasikan dalam JTP2IPS.

\section{METODE}

\section{Metode pelaksanaan kegiatan}

pengabdian ini adalah in-service training program yaitu pelatihan dan pendampingan kepada guru-guru IPS MTs Kabupaten Malang. Adapun langkah-langkah kegiatan yang ditempuh secara rinci seperti pada gambar 1.

\section{Penyemaian Informasi}

Pada tahap pembekalan ini, pertama peserta diperkenalkan atau diberikan informasi tentang hakikat artikel ilmiah dan berbagai jenis artikel yang terdapat dalam jurnal-jurnal. Kemudian menganalisis kerangka isi yang terdapat dalam artikel secara keseluruhan. Membandingkan kerangka isi dari berbagai artikel dalam beberapa jurnal. Kemudian langkah terakhir pada tahap ini memberikan pedoman penulisan artikel sesuai dengan gaya selingkung JTP2IPS.

\section{Pendampingan Penyusunan}

\section{Artikel IImiah}

Kegiatan selanjutnya adalah praktik, dimana peserta menulis artikel ilmiah berdasarkan hasil-hasil penelitian atau gagasan ilmiahnya. Sebelumnya masingmasing peserta sudah diminta membawa artikel. Jadi selama penulisan ini peserta dibimbing oleh tim pengabdian untuk menyempurnakan artikel masing-masing 
peserta sesuai dengan gaya selingkung JTP2IPS. Apabila belum selesai pada hari itu, peserta diberi waktu untuk melanjutkan penulisan artikel di rumah dan kemudian dalam rangka penyempurnaan artikel tersebut tim pengabdian akan memberikan bimbingan melalui surel secara berkala sampai artikel tersebut layak dimuat dalam jurnal JTP2IPS.

\section{Evaluasi}

Tim melakukan evaluasi secara keseluruhan untuk mengetahui tingkat keberhasilan program. Keberhasilan program dapat diketahui dari data kuantitatif jumlah artikel yang telah terpublish dalam JTP2IPS.

\section{HASIL DAN PEMBAHASAN}

Kegiatan pengabdian kepada masyarakat ini dilaksanakan sehari, yaitu pada hari Kamis tanggal 30 Maret 2017 dari pukul 08.30-16.00 WIB. Produk yang dihasilkan dalam kegiatan ini adalah artikel hasil penelitian yang nantinya akan dimasukkan dalam Jurnal Teori dan Praksis Pembelajaran IPS (JTP2IPS) bagi artikel yang layak. Jumlah peserta yang hadir pada kegiatan pelatihan dan pendampingan ini sebanyak 25 guru IPS MTs yang berasal dari Kabupaten Malang. Peserta sangat antusias mengikuti kegiatan dari sesi ke sesi. Kegiatan tersebut dibagi kedalam tiga sesi. Sesi pertama yaitu penyampaian materi, sesi kedua yaitu tanya jawab, dan sesi ketiga pendampingan penyusunan artikel (praktik penyusunan artikel).

Pelaksanaan kegiatan ini dilakukan oleh 2 orang tim dengan pokok bahasan yang disampaikan mengenai: 1) konsep secara umum artikel hasil penelitian (pengertian artikel hasil penelitian, sistematika penulisan artikel hasil penelitian, dan teknik penulisan artikel hasil penelitian); 2) pedoman penulisan artikel yang sesuai dengan selingkung JTP2IPS.

Peserta sangat bersemangat pada sesi tanya jawab, terutama saat membahas tentang kaedah penulisan artikel ilmiah. Hal ini disebabkan karena mereka belum pernah memperoleh materi atau pelatihan tentang penulisan artikel ilmiah sebelumnya. Secara garis besar inti dari pertanyaan para peserta adalah apa perbedaan artikel dengan jurnal? apakah bisa satu laporan penelitian dijadikan menjadi beberapa artikel? untuk penulisan daftar pustaka apakah yang dibaca kemudian tidak dikutip bisa dimasukkan di daftar pustaka? pada bagian pembahasan isinya apa, dan kemudaian ada hasil dan pembahasan, apa perbedaannya? dan masih banyak pertanyaan lain.

Berdasarkan penuturan peserta, kesulitan mendasar yang banyak dialami dalam menyusun artikel yaitu merasa sulit ketika mengawali membuat penelitian, karena pada dasarnya penelitian ini akan dijadikan bahan dalan menyusun artikel. Kesulitan ini berawal dari tidak adanya ide yang akan dituangkan dalam penelitian. Ide tidak muncul karena budaya membaca dan menulis belum menjadi kebiasaan. Itulah permasalahan mendasar yang mempengaruhi rendahnya budaya menulis di kalangan guru-guru. Hal ini senada dengan pendapat Budiharso (2006: 59-63), bahwa "masalah pokok dalam menulis karya ilmiah dapat dikelompokkan ke dalam 
Pelatihan dan Pendampingan Penulisan Artikel Jurnal Bagi Guru-Guru IPS...

masalah empiris, masalah retorika, dan masalah linguistik".

Berdasarkan hasil pengabdian diketahui bahwasanya kegiatan menulis khususnya menulis artikel hasil penelitian memang bukanlah pekerjaan yang mudah. Untuk dapat menghasilkan tulisan yang baik, diperlukan latihan yang berulang kali, ketekunan, dan kebiasaan. Meskipun demikian peserta sadar bahwa ketika ada keinginan yang kuat keterampilan menulis ini dapat dipelajari dengan mudah. Peserta menuturkan jika ada beberapa masalah pokok yang menyebabkan peserta sulit untuk membuat tulisan yaitu keterbatasan dalam mengembangkan ide, pola tulisan, dab tulisan kurang berbobot.

Hal tersebut di atas diperkuat dengan kenyataan bahawa seluruh peserta belum bisa menyelesaikan artikelnya 100\% karena ada dari mereka yang memang sudah membawa bahan laporan penelitian untuk diubah menjadi artikel dan ada yang belum. Padahal sebelum kegiatan ini dilaksanakan, persyaratan wajib peserta sebelum mengikuti kegiatan pelatihan adalah membawa laporan penelitian yang telah mereka miliki misalnya skripsi, PTK, maupun laporan penelitian yang lain. Ada beberapa yang membawa dan ada beberapa yang memang tidak memiiki. Bagi yang sudah membawa, mereka dapat menyelesaikan artikelnya kurang lebih $40 \%$ yaitu sampai pada bagian metode penelitian. Bagi yang belum selesai, pemateri atau instruktur memberi kesempatan kepada seluruh peserta untuk melanjutkan atau menyelesaikan artikelnya di rumah, dengan catatan artikel yang sudah selesai harus dikirimkan kembali melalui e-mail untuk memperoleh umpan balik.

Hasil evaluasi terhadap kuantitas dan kualitas artikel yang telah dibuat peserta dengan keberlanjutan pendampingan melalui e-mail dari kegiatan pengabdian ini adalah sebagai berikut. Hanya ada satu guru yang mengumpulkan artikel ilmiah yang akan diterbitkan dalam JTP2IPS dengan judul "Peran Wisata Religi Makam Gus Dur dalam Membangun Kehidupan Sosial Ekonomi Masyarakat di Sekitar Pondok Pesantren Tebuireng Jombang". Alasan klasik yang selalu diutarakan guru mengapa tidak bisa mengumpulkan karena 1) mereka sibuk mengajar sehingga tidak sempat menulis, 2) mereka baru memulai penelitian sehingga belum ada bahan hasil penelitian yang akan ditulis menjadi artikel. Walaupun demikian, mereka merasa memiliki wawasan tentang penulisan artikel ilmiah. Patut disyukuri bersama bahwa kegiatan pengabdian pada masyarakat ini memberikan hasil antara lain meningkatnya jalinan kerjasama antara prodi P.IPS dengan guru-guru IPS MGMP Kabupaten Malang, meningkatkan pengetahuan dan keterampilan guru-guru IPS dalam merancang dan menyusun artikel. Selain dapat memberikan wawasan dan keterampilan kepada mereka dalam menulis artikel ilmiah, mereka juga merasa lebih percaya diri dalam membimbing siswa dalam pembuatan karya tulis ilmiah.

Beberapa faktor yang mendukung terlaksananya kegiatan pengabdian pada masyarakat ini adalah besarnya minat dan antusiasme peserta selama kegiatan, 
sehingga kegiatan berlangsung dengan lancar dan efektif. Sedangkan faktor penghambatnya adalah 1) terbatasnya kemampuan guru dalam mengoperasikan komputer sehingga menghambat penulisan artikel, 2) keterbatasan waktu pelatihan, 3) ada beberapa peserta yang tidak membawa bahan yaitu berupa laporan penelitian, sehingga ketika pelatihan mereka kebingungan, 4) para guru belum pernah menulis artikel jurnal hasil penelitian, sehingga di awal agak berat mendampinginnya, namun dengan bantuan dan keterlibatan beberapa mahasiswa dalam kegiatan ini, masalah tersebut bisa teratasi.

Di akhir kegiatan, peserta memberikan masukan dan saran terkait dengan pelaksanaan pengabdian ini. Masukan dan saran peserta antara lain adalah 1) terkait jumlah peserta, jumlah peserta diharapkan lebih dari 25; 2) kegiatan seperti pelatihan artikel ilmiah ini kalau bisa dilakukan setiap bulan, mengingat setiap bulan ada jadwal MGMP, sehingga bisa mengisi kegiatan MGMP; 3) mengingat besarnya manfaat kegiatan pengabdian pada masyarakat ini, maka saran peserta untuk tahun-tahun berikutnya atau pengabdian berikutnya mengharapkan adanya kegiatan seperti pelatihan kembali dengan tema yang berbeda misalnya workshop tentang pembuatan modul, penilaian pembelajaran, dan modelmodel pembelajaran, 4) diharapkan kegiatan pelatihan-pelatihan bisa merata menjangkau seluruh wilayah baik utara, selatan, barat, maupun timur secara bergantian.

\section{KESIMPULAN}

Secara keseluruhan kegiatan pelatihan penulisan artikel jurnal ini dapat dikatakan berhasil, meskipun belum semua peserta pendampingan menguasai dengan baik materi yang disampaikan. Kegiatan ini mendapat sambutan baik terbukti dengan keaktifan peserta mengikulti pelatihan dengan tidak meninggalkan tempat sebelum pelatihan berakhir. Selain itu keberhasilan dapat dikukur dari rencana jumlah produk artikel ilmiah yang dapat dihasilkan oleh guru-guru IPS di Kabupaten Malang yang siap dipublikasikan dalam jurnal JTP2IPS, meskipun hanya ada 1 artikel. Oleh sebab itu, perlu adanya pendampingan lebih lanjut untuk meningkatkan jumlah artikel yang siap dipublikasikan.

\section{DAFTAR RUJUKAN}

Budiharso, Teguh. 2006. Panduan Lengkap Penulisan Karya Ilmiah. Yogyakarta: Gala IImu

Hadriyanto, Soleh. 2013. Peningkatan Karier Guru Melalui Kemampuan Penulisan Karya Ilmiah. Bandung: Makalah disampaikan dalam Seminar Upacara Penyerahan ljazah UT UPBJJ Bandung.

Peraturan Menteri Pendayagunaan Aparatur Negara dan Reformasi Birokrasi No. 16 Tahun 2009. Tentang Jabatan Fungsional Guru dan Angka Kreditnya

Tatang, M. Amirin. 2006. Menulis Karya IImiah (Artikel). Makalah Pelatihan Penulisan Karya Ilmiah Bagi Guru-guru seIndonesia. Yogyakarta, 2-3 November.

UU Nomor 20 Tahun 2003 Tentang Sistem Pendidikan Nasional

UU Nomor 14 Tahun 2005 Tentang Guru dan Dosen. 